\title{
Commodity Studies with Polanyi: Disembedding and Re-Embedding Labour and Land in Contemporary Capitalism
}

\author{
Ernst Langthaler $\cdot$ Elke Schüßler
}

(C) The Author(s) 2019

\begin{abstract}
This article aims to inform current debates in the field of transnational commodity studies through a Polanyian lens. Polanyi reminds us of the need to pay attention to the "double movements" in which fictitious commodities are disembedded from and re-embedded in society. We focus on two fictitious commodities, labour and land, which are conventionally treated as mere inputs for the production of genuine commodities. Through investigating the disembedding and re-embedding of labour in the garment industry, and of land in the agro-food sector since the 1970s, we gain insights regarding the commodification of fictitious commodities in the context of transnational commodity chains. The developments in both fields imply not just simple double movements, but complex entanglements of disembedding and reembedding dynamics at the interface of state, business and civil society actors.
\end{abstract}

Keywords Fictitious commodities - Commodity chains - Global production networks · Garment industry · Agro-food industry

\section{Warenstudien mit Polanyi: Entbettung und Wiedereinbettung von Arbeit und Land im aktuellen Kapitalismus}

Zusammenfassung Dieser Text entwickelt eine Polanyi'sche Sichtweise auf die Forschung zu transnationalen Warenketten. Karl Polanyis Analyse einer „Großen Transformation“ schärft hierbei insbesondere den Blick für eine sogenannte Dop-

Both authors have contributed equally to the development of this paper. Author names are therefore in alphabetical order.

\footnotetext{
E. Langthaler $(\bowtie) \cdot$ E. Schüßler

Johannes Kepler University Linz, Altenberger Straße 69, 4040 Linz, Austria

E-Mail: ernst.langthaler@jku.at

E. Schüßler

E-Mail: elke.schuessler@jku.at
} 
pelbewegung der Einbettung und Entbettung von fiktiven Waren in der Gesellschaft. Basierend auf einer empirischen Analyse von zwei fiktiven Waren, Arbeit in der Bekleidungsindustrie und Land im Agrar- und Ernährungssektor, gehen wir über eine Betrachtung von Arbeit und Land als reine Inputfaktoren hinaus hin zu einem komplexeren Verständnis der Ein- und Entbettungsdynamiken globaler Warenketten. Insbesondere betonen wir hierbei die Rolle von Staaten, Unternehmen und der Zivilgesellschaft als Treiber wechselseitig verflochtener Ein- und Entbettungsbewegungen.

Schlüsselwörter Fiktive Waren - Globale Warenketten · Bekleidungsindustrie · Landwirtschaft und Ernährung

\section{Introduction}

Globally interconnected flows of production, typically coordinated by a multinational lead firm and often referred to as global commodity chains or global value chains, are a cornerstone of today's economy. While the phenomena of global trade and foreign direct investment is not new, both have risen exponentially in the last decades (UNCTAD 2013), potentially bringing growth and prosperity to what has in the past been seen as the (semi-)periphery of the industrial core regions (Wallerstein 1974). At the same time, global production intensifies the time-space distantiation of economic exchanges from local communities and is associated with widespread labour exploitation, environmental pollution and the destruction of financial value. Thus, while commodity chains spanning the globe are both outcomes and drivers of a dynamic of disembedding markets from society in a Polanyian sense, diverse public and private actors on multiple levels have sought to re-embed economic activities through a dense network of (trans-)national regulation in recent decades.

In the context of these debates, Polanyi's critical account of capitalist development and his central idea that market society cannot sustain itself in the long run because it destroys the social and environmental relations that are the basis of a sustainable use of human and natural resources seem timely. A central tenet of this article is that there is no better place to see this incompatibility than in the context of transnational commodity chains ${ }^{1}$. In Polanyi's work, the concept of (fictitious) commodities and the related dynamics of (de-)commodification are central. Although Polanyi failed to predict this new wave of marketization, land, labour and money are now commodified in a highly interlinked way and on an unprecedented transnational scale (Burawoy 2010). The concept of commodity is also central in the interdisciplinary field of commodity chain research that has developed since the coining of the term by Hopkins and Wallerstein (1977). Wallerstein (1983), who mentions Polanyi as one of his core sources of inspiration (Block and Somers 2014), shares Polanyi's interest in the way commodity chains relate to society, particularly regarding the

\footnotetext{
1 In what follows, we will use the term "transnational commodity chains" to refer to our empirical phenomenon of interest and to avoid the use of more conceptually loaded terms like "global commodity chains", "global value chains" or "global production networks".
} 
production of labour as a core input factor. For this reason, we propose to connect current debates in the field of commodity research with a Polanyian perspective, derived mainly from his major work The Great Transformation (TGT) published in 1944.

In what follows, we stress two avenues in which a Polanyian lens can enrich current debates in the field of commodity studies. First, commodity chain research should take the commodification of land, labour and money, typically viewed as inputs for the production of other commodities, more seriously. Second, and relatedly, commodity chain research should pay closer attention to the "double movement" in which commodities are disembedded from and re-embedded in society. Here the state and other regulatory actors should not just be seen as a corrective to dysfunctional markets, but also as deeply involved in creating the conditions for marketization. The central question from a Polanyian perspective is not how commodity chains can be governed more efficiently, but what the consequences of disembedded commodity chains are for the environment, and for society at large. After developing these arguments in more detail, we will provide two case studies that demonstrate the value of a Polanyian lens in contemporary commodity studies, as well as of the necessary extensions of Polanyi's framework when applied to analysing the current global economy. Data for the two case studies were collected in the context of two extensive research projects: one on the impact of the Rana Plaza factory collapse on labour standards in the global garment industry (cf. Schuessler et al. 2018), and one on the emergence of soy-based global commodity chains in the twentieth century (Langthaler 2015, 2018; Krausmann and Langthaler 2019). Due to length constraints, in this article we only provide a brief summary of the main findings and surrounding theoretical debates in the two industries.

\section{Double movements around fictitious commodities}

The commodity concept provides a cornerstone of modern economics, beginning with Adam Smith, David Ricardo and Karl Marx who defined it as a value-bearing product to be sold and bought in the market (Sammond 2007). While Polanyi takes up these theoretical strands in TGT, he draws a distinction between genuine and fictitious commodities: whereas the former are conceived as "objects [i.e. goods and services] produced for sale on the market" (Polanyi 2001, p. 75), the latter are not produced for market sale. This distinction originates from Ferdinand Tönnies, who emphasized the "artificiality" of market contracts and their "fictitious commodities" (Dale 2010, p. 71).

In TGT, Polanyi highlights three fictitious commodities:

Labor is only another name for a human activity which goes with life itself, which in its turn is not produced for sale but for entirely different reasons, nor can that activity be detached from the rest of life, be stored or mobilized; land is only another name for nature, which is not produced by man; actual money, finally, is merely a token of purchasing power which, as a rule, is not produced at all, but comes into being through the mechanism of banking or state finance (Polanyi 2001, pp. 75-76). 
In contrast to (neo-)classical economics, which subsume these entities under the category of genuine commodities, Polanyi states that "the commodity description of labor, land, and money is entirely fictitious" (Polanyi 2001, p. 76). For Polanyi, the commodity fiction emerges from the dissolution of the pre-capitalist embeddedness of labour, land and money in society. These non-commodities were commodified only in the capitalist era through a process of disembedding the economy from society by the liberal nation state (Polanyi 2001, pp. 71-80). The Polanyian distinction between genuine and fictitious commodities grounds the leitmotif of TGT because the commodification of man and nature through the realization of the "free market" utopia is said to lead to disaster: "to allow the market mechanism to be sole director of the fate of human beings and their natural environment [...] would result in the demolition of society" (Polanyi 2001, p. 76). Once the disruptive effects of the "free market" become apparent, Polanyi assumed that people would refuse to act like lemmings marching over a cliff to their own destruction. Instead, he argued that they would retreat from the tenets of market self-regulation to protect society and environment.

According to Polanyi, this shift from disembedding to (re-)embedding marks a "double movement" that can be observed in the nineteenth and early twentieth century: "the extension of the market organization in respect to genuine commodities was accompanied by its restriction in respect to fictitious ones" (Polanyi 2001, p. 79). TGT hereby emphasizes state-led countermovements to marketization, comprising regimes as diverse as Soviet bolshevism, German fascism and the US New Deal (Polanyi 2001, pp. 245-256). Polanyi's use of the term "embeddedness" refers to the task of "stabilizing a (democratic) organization of society through the institutional regulation of markets", especially in the realm of land, labour and money, i.e. the fictitious commodities (Beckert 2007).

TGT can be read as a history of capitalist globalization avant la lettre (Osterhammel and Petersson 2003) of what is usually termed the "first wave of globalization", from the emergence of a network of international free trade agreements based on the gold standard in the 1860 s to the breakdown of political attempts to restore this economic system after the disruptions of the First World War, resulting in the Great Depression of the 1930s (Tooze 2014; McMichael 2013). Polanyi did not take into account another wave of free-market fundamentalism after the establishment of protective regimes, ranging from Soviet communism to German fascism. However, scholars of globalization studies argue that the relevance of TGT is not confined to a specific historical period (Steger 2009, p. 131). Many see parallels between Polanyi's analysis and current developments under the "second wave of globalization", ranging from the dissolution of state-organized capitalism ("Fordism") based on the Bretton Woods compromise by neoliberal governments, corporate actors and intellectual elites in the 1980s and 1990s to the economic and political disruptions of the Great Recession from 2008 onwards (Tooze 2018; McMichael 2013).

However, with intensified globalization since the 1970s, it seems that land, labour and money have become increasingly commodified and detached from society, spurring an intense debate around adequate forms of public and private regulation in the transnational realm. Polanyi's commodity concept which, according to Dale (2010, p. 77), signifies a "thing" in the Tönniesian sense rather than a "social 
relation" in the Marxian sense, lacks any notion of transnational relations. Thus, we propose to complement it with the notion of commodity chains:

What we mean by such chains is the following: take an ultimate consumable item and trace back the set of inputs that culminated in this item, including prior transformations, the raw materials, the transportation mechanisms, the labor input into each of the material processes, the food inputs into the labor. This linked set of processes we call a commodity chain (Hopkins and Wallerstein 1977, p. 128).

World-systems analysts apply the commodity chain concept to reveal the emergence of an international division of labour incorporating core and (semi-)peripheral regions into a global capitalist economy. An emphasis is on political power shaping waves of expansion and contraction in the world economy (Bair 2008a). More recent approaches, most importantly global commodity chains (GCCs) (Gereffi 1994) and global value chains (GVCs) (Humphrey and Schmitz 2000), have shifted away from this long-term, world-historical perspective deeply rooted in socio-economic thinking towards a more short-term, narrowly industry and firm-centred analysis (Bair 2005). The GCC approach focuses on the modes of governing buyer-supplier relationships and comprises several dimensions: the transformation of raw materials and other inputs into final products; the spatial configuration; the governance structure, which oscillates between producer-driven and buyer-driven chains; and the institutional "rules of the game" (Gereffi 1994, 1995). The GVC approach has further differentiated this typology into five governance structures (hierarchy, captive, relational, modular and market), determined by three variables: the complexity of transactions, the ability to codify transactions and the capabilities of the supply base (Gereffi et al. 2005).

More recently, the "Manchester School" of economic geography has pushed for a "re-embedding" of commodity chain research under the label of global production networks (GPN) (Bair 2008a, 2008b). In contrast to GCC and GVC approaches, GPN scholarship emphasizes the multiscalar dynamics of globalization. i.e. the embeddedness of global networks in national, regional and local contexts (Hess and Coe 2006). It also stresses the role of the state as a regulatory influence on commodity chains as well as the role of non-economic actors in shaping commodity chains. The sheer size of this flourishing literature underscores the appeal of chain and network metaphors as tools to conceptualize globalization dynamics in the field of commodity studies.

A Polanyian lens can enrich current debates in this field, where an intense debate has developed regarding the adequate regulation of commodity chains in the light of their negative externalities. This debate has, for a long time, focused on private forms of regulation exerted unilaterally by corporations or multilaterally in the form of multi-stakeholder initiatives (MSIs) because of an alleged "regulatory gap" in the transnational arena. Only recently are public and more legally binding forms of regulation receiving renewed attention, not least because corporations lack democratic legitimacy for regulation. These dynamics have led to the emergence of a dense transnational institutional framework for which not one, but multiple public and private actors on different levels of analysis are responsible (Djelic and 
Quack 2018). Globalization hereby does not necessarily imply a weakening of state power, but rather a transformation of the state into a "competition" (Cerny 1997) or "entrepreneurial" (Mazzucato 2011) one.

This recent stream of research thus resonates well with Polanyian thought. Clearly, Polanyi's analysis falls short of anticipating the complex transnational linkages in the way labour, land and money are being commodified in this new international division of labour. Yet, Polanyi reminds us of the need to pay attention to the double movements in which fictitious commodities are disembedded from and re-embedded in society. While Polanyi provides a strong analysis of the role of the state as a driver of both disembedding and re-embedding dynamics, the GPN approach unpacks the role of society—largely a black box in Polanyi's framework (Burawoy 2010)—by differentiating economic actors from civil society ones such as trade unions, NGOs or consumers, all of which can be potential drivers of countermovements. However, while the GPN approach tends to see countermovements as progressive, Polanyi reminds us of both progressive and reactionary forces striving for a re-embedding of markets, fascism framed as "national socialism" being a prime example of the latter. We now empirically illustrate double movements around labour and land as fictitious commodities in the transnational garment industry and the agro-food sector to illustrate the value of a Polanyian lens on contemporary commodity chains.

\section{Double movements around labour}

The garment industry has been a forerunner in an international division of labour since the 1970s and, as such, is a prime example for studying double movements regarding labour as a fictitious commodity. The value of the global garment market is estimated at over $€ 2.6$ trillion in $2018^{2}$. In 2015 , the highest consumer expenditure on apparel in the EU was in the UK, at $€ 70.1$ billion, followed by Germany with $€ 61.7$ billion $^{3}$. The industry is growing at a rate of about 5 per cent annually. A main driver of this growth in recent years has been the adoption of the fast fashion business model by garment retailers such as Zara (Inditex) and H\&M: instead of shopping for garments every two to four seasons, consumers in the West can now find new fashionable garments at low cost in stores every two to three weeks, bought to be worn only a few times before being discarded.

Driven both by a search for cheap labour power, which was dwindling in the quickly industrializing West, and in search of low wages, Western lead firms began outsourcing almost all of their production to Eastern Europe, North Africa, Asia or Latin America back in the 1970s. This development was supported by state-driven trade liberalization. German firms benefitted from so-called "outward processing trade" regulations as early as 1966, when import taxes were cut for the outsourcing of cutting and sewing tasks to subcontractors in Eastern Europe (Schüßler 2009). This practice was later complemented by the multi-fibre agreement (MFA), one of

\footnotetext{
2 https://fashionunited.com/global-fashion-industry-statistics [accessed 29.9.2018].

${ }^{3}$ https://www.statista.com/statistics/419877/clothing-consumption-expenditure-europe-eu/ [accessed 29.9.2018].
} 
the world's most comprehensive protectionist regimes founded in 1974 to protect European and US-American garment and textile markets from cheap imports on the basis of quotas. While these regulations allowed a highly state-controlled form of internationalization, the foundation of the World Trade Organization in 1994 and the stepwise phase-out of the quota-based system up to 2005 rapidly intensified competitive dynamics. China quickly became the world's largest exporter of garments. The industry has since become highly concentrated, ever increasing the large retailers' buying power due to their ability to import large volumes of garments at a low price. In the 1990s, experts were already warning of an increasing squeeze on prices leading to substandard wages and unsafe working conditions at most supplier sites (Gereffi 1994).

Since the 1980s, Bangladesh has invested in building up its garment production and, with China's own industrialization rapidly progressing, quickly moved up to become the world's second largest garment export nation due to low labour costs and large production capacities. Today, garments represent more than $80 \%$ of Bangladesh's exports and around a quarter of the country's GDP. The spread of the fast fashion business model has in recent years created more pressure on labour costs and lead times than already existed in this highly labour-intensive and cost-competitive industry. Based on an extensive factory survey, Anner (2018) reports a 13 per cent decline in the nominal price paid for trousers exported from Bangladesh to the United States between 2011 and 2016, only a small percentage of which can be attributed to exchange rate fluctuations or falling cotton prices. While initially garment workers, and especially women from rural households, were able to reduce their poverty level, albeit under difficult conditions (Kabeer and Mahmud 2004), wages have dropped significantly in recent years. With an average income of US \$64 a month, Bangladeshi garment workers do not even earn a living wage (Baumann-Pauly et al. 2018).

In the midst of these dynamics, the Rana Plaza factory building collapsed in Bangladesh on 24 April, 2013, leaving an estimated 1130 mainly female garment workers dead and more than 1500 persons injured. Whereas the employees of other enterprises in the same building were told not to go to work when the building started showing visible cracks, the garment workers were forced to enter the building, showing in its most direct way the treatment of people as commodities-and its destructive consequences. This constituted a focusing event in the industry (Schuessler et al. 2018), unveiling the ineffectiveness of extant regulations in ensuring the safety of workers at a very basic level. World-wide public indignation enabled NGOs and unions at international, national and local levels to campaign successfully for a multi-stakeholder arrangement intended to improve and regulate factory safety in Bangladesh. This arrangement is known as the Accord on Fire and Building Safety in Bangladesh ("Accord"), signed by global trade unions IndustriALL and UNI Global, trade unions in Bangladesh, and over 200 retailers and brands from 20 countries in Europe, North America, Asia and Australia. The Accord represents a departure from existing global labour governance initiatives in that it is legally binding (Anner et al. 2013). 
The principle of limited liability by which lead firms are not legally responsible for the actions of their suppliers at home or overseas is now increasingly being questioned in this industry. Rather than delegating responsibility for labour standards solely to corporations, governments are placing trade relations back on their own agendas, as seen in the UN Guiding Principles on Business and Human Rights, the EU Directive 2014/95/EU on non-financial reporting or the 2015 UK Modern Slavery Act. Furthermore, at least some large Western brands and retailers are trying to counteract the "race to the bottom" dynamic by beginning to act collectively, often in collaboration with global union federations, to gain leverage not just over suppliers' working conditions (Alexander et al. 2017; Helfen et al. 2018) but also over production prices, which continue to fall (Schüßler et al. 2019). Possibly because of this double-edged effect, initiatives such as the Accord now face intense resistance by the Bangladeshi government, industry and even local union activists. Thus, as buyers and other Western actors (mostly NGOs, unions and governments) seek to gain some control over pure market forces, they do so by focusing on the points of production, whereas suppliers and their governments would like to see a re-embedding on the side of consumption, i. e. a regulation of consumer behaviour and the fast fashion business model (Lohmeyer and Schüßler 2018).

In sum, the garment commodity chain in its historical development provides a case par excellence for illustrating Polanyi's argument, since the most disastrous commodification of garment workers unfolded in times where state regulation was weakest. It illustrates the importance of society-driven countermovements such as NGO action or the ILO's Better Work programme that have surely brought about some improvements for garment workers, but also indicates their limitations as a re-embedding force. Arguably, the increased state involvement in re-embedding garment commodity chains and the openness to firm collective action with unions evidenced today in Bangladesh are not unfolding on moral grounds or better insight, as Polanyi might suggest, but because buyers currently face little alternative to sourcing large volumes of garments from Bangladesh, where they face public scrutiny. Collectively, re-embedding focuses not on the decommodification of labour, but on averting the most detrimental effects of this commodification through adequate regulation. While garment workers in Bangladesh report some improvements in other areas such as wages and overtime, re-embedding since Rana Plaza remains selective at best, with most improvements evidenced in the area of building safety (Schüßler et al. 2019). At the same time, buyers are not only gaining power over suppliers by increasing their focus on transparency and collective action, but also seeking to decrease their dependency on Bangladesh as a sourcing location by investing in Africa - albeit still in small volumes to date-or exploring automation. Thus, continued struggles for re-embedding are needed to more fundamentally alter the power dynamics between capital and labour in contemporary garment commodity chains (Lohmeyer et al. 2018). 


\section{Double movements around land}

The agro-food sector has become another arena of the double movement of global capitalism since the 1970s. Most importantly, the feed-livestock-meat complex, which experienced outstanding economic growth, also raised social and environmental concerns about excessive meat production and consumption (Weis 2013). Europeans eat large amounts of meat, and pork is their favourite variety. In 2013, an average EU citizen consumed $82 \mathrm{~kg}$ of meat - nearly twice as high as the global average of $43 \mathrm{~kg}$. The high level of meat intake reflects the nutrition transition from the mid-twentieth century onwards, converging into a "Western diet" rich in animal products, sugar and vegetable oils (Langthaler 2018). "Meatification" emerged as an element of affluent European lifestyles, signifying wealth, strength and masculinity (Weis 2013). European appetite for meat is met by the strongly concentrated livestock industry, which has its gravity centre in the northwest of the continent. Most of the $44.5 \mathrm{mt}$ of meat produced in the EU in 2013 was pork (50\%), followed by poultry (29\%) and bovine meat (17\%) (Faostat 2018; Heinrich Böll Foundation 2014 , p. 60). Working conditions in the meat-packing industry, which has high rates of migrant and female labour, are poor, and methane and slurry emissions from the livestock factories pollute the atmosphere and hydrosphere (Weis 2013).

Large-scale pig production relies on two basic feedstuffs: maize as a source of carbohydrates and soymeal as a source of protein. While the former comes from European production for the most part, the latter is imported almost exclusively from overseas. Until the 1970s, the USA as the world's soy powerhouse in the Cold War era was the European Economic Community's main supplier of soymeal, imported duty-free under the GATT framework. From the 1970s onwards, the gravity centre of soy expansion shifted from North to South America (Langthaler 2015). Since then, Brazil and Argentina have been strengthening their position in the European market: sales of soybeans and bean equivalents of soymeal to the EU rose from $10.8 \mathrm{mt}$ in $1986 / 88$ to $34.5 \mathrm{mt}$ in 2001/03. Whereas Brazilian and Argentinian imports initially equalled US imports, they ended up surpassing them fivefold. Up to 2014/16, Brazilian and Argentinian deliveries to the EU had declined to $25.3 \mathrm{mt}$, which still equalled more than four times the US imports (Faostat 2018).

Transatlantic trading and processing of soybeans and soymeal is controlled mostly by US-based companies, situated at the "bottlenecks" of the commodity chain between North and South American feed producers and European livestock feeders. Around the year 2000, $80 \%$ of the European crushing industry was controlled by Archer Daniels Midland, Bunge and Cargill. Concentrated market power allows these companies to push down purchase prices and to jack up sales prices, thereby maximizing profits. Despite US debates on "national loyalty", flexible transactions enable these transnationals to profit from any differences whatsoever in supply, demand, prices, subsidies, tax breaks, labour or environmental standards between world regions (Vorley 2003, pp. 39-44).

Through large-scale imports of feedstuffs, the EU has extended its access to land beyond its borders, thereby expanding the worldwide agricultural frontier (Krausmann and Langthaler 2019). The European "hoofprint" on overseas regions is mainly located in South America, first and foremost in Brazil. The area used in Brazil to 
produce soybeans for export to the EU grew from 4.7 million ha or $49 \%$ of the total soy area in $1986 / 88$ to 8.0 million ha or $50 \%$ in $2001 / 03$, before declining to 5.0 million ha or $16 \%$ in $2014 / 16$ due to shifts to other markets, most importantly China. Thus, European demand for animal feed, in addition to other external and internal forces, was a major driver of soy expansion in Brazil since the 1970s, shifting from the South to the Central-West Region. The harvested soy area grew 3.8fold from 2.7 to 10.5 million ha from 1970/74 to 1990/94 and further increased 2.5-fold to 26.1 million ha in 2010/14 (Faostat 2018). Soy expansion involved the substitution of the human labour force through agro-industrial technologies such as herbicide-resistant transgenic seeds, broad-spectrum herbicides and large-scale machinery, delivered by mostly US-based agribusiness firms. Due to economies of scale, the concentration of farm size in soybean production, and hence income inequality, progressed faster than in the rest of agriculture (Turzi 2017, pp. 83-97).

Brazil's soy expansion was not only a burden on the environment, expressed through deforestation, greenhouse gas emission, biodiversity loss, soil erosion and water pollution, but also eroded rural society through the "accumulation through dispossession" (Harvey 2004) of land, i.e. the transfer of natural resources as public assets of rural communities into private property of agribusiness enterprises (Cáceres 2014). As agricultural land became a highly valued commodity, capital-rich commercial farms, mostly owned by farmers of European or US descent, expanded at the expense of indigenous and peasant communities, which often lacked secure property rights. Besides escalating prices in the booming land market, extra-economic pressures contributed to the displacement of small landowners as well: social isolation due to enclosure by large soy farms pressed peasants to abandon their land. Collateral damage of agro-industrial farming, e.g. agrochemical drifts from large soy fields, harmed neighbouring people as well as their livestock and non-transgenic crops. Cases of brute violence by ranchers and soy planters, including murders, were documented in large number. Some displaced campesinos partly resorted to ruralurban migration to make a living; others stayed in the countryside, often lacking a roof over their heads, as underpaid wage labourers or even slave-like workers; and yet others flocked to the communities of landless movements (Lapegna 2016, pp. 84-114; Turzi 2017, pp. 95-96).

The accumulation of land, disembedded from rural communities and their environments, in the hands of the wealthy and powerful agribusiness elite fuelled diverse countermovements. In the 1990s, displaced rural people formed the Landless Rural Workers' Movement (MST), the largest social movement in Latin America. Through land occupation according to the constitution of 1988, the MST resettled landless peasants on active or fallow latifundias, gaining public visibility and pushing land reform onto the political agenda. The MST advocates cooperative forms of work and decision-making to improve the sustainability of peasant communities and their environment. It belonged to the social movements' coalition that supported and was co-opted by the left-wing governments of Presidents Lula da Silva and Rousseff from 2003 to 2016 (Robles and Veltmeyer 2015, pp. 189-195). A less radical and more reformist initiative against the negative externalities of the Brazilian soy expansion evolved with the Roundtable of Responsible Soy (RTRS), a global multistakeholder arrangement of producers, processors, traders and civil society organi- 
zations (Hospes 2014). Besides these radical and reformist forces, soy expansion also faced resistance from non-human actors. Some years after the introduction of transgenic seeds, soy farmers were worried by the appearance of herbicide-tolerant weeds on their fields. These "superweeds", created through gene transfer from soy to wild plants ("gene-jumping"), resisted normal doses of glyphosate, the ordinary broad-spectrum herbicide. As a consequence, agro-industrial soy farming became more troublesome and costly, thus raising effort and reducing profits (Lapegna 2016, pp. 37-45).

Despite human and non-human countermovements to the soy boom through civic mobilization and "gene-jumping", the re-embedding of land into society and environment met severe obstacles. The MST's orientation towards food sovereignty provoked harsh opposition from the agribusiness elite, relying on strong power alliances to defend their interests. Their congressional arm, the bancada ruralista, enabled them by blocking or voting through legislative initiatives. Outside the parliament, large landowners, in alliance with provincial and municipal authorities, successfully used the courts to challenge land expropriations. Most importantly, the left-wing governments sided with export-oriented agribusiness as a revenue-increasing model of development, encouraging its growth with legal and financial incentives (Turzi 2017, p. 96; Robles and Veltmeyer 2015, pp. 193-194). Similar to the MST, the "superweeds" were marginalized as well: the agrochemical industry soon reacted to the soy farmers' demand by supplying new mixtures of herbicides for eliminating both conventional weeds and "superweeds" (Lapegna 2016, pp. 37-45). However, countermovements to the commodification of land emerged not only on the producer side, but also on the consumer side of the agro-food chain. While activities stressing the power of affluent consumers were limited in scope, other movements such as La Via Campesina promoting peasant communities and agroecological farming built transcontinental alliances between producers and consumers (McMichael 2013). Due to public concerns about unsustainable soy expansion in South America, agribusiness actors, in line with the EU "protein strategy", have been promoting non-transgenic production in Central, East and Southeast Europe ("Danube Soya") (Krön and Bittner 2015).

In sum, the development of the feed-livestock-meat complex between South America and Europe in the past decades reveals the ambivalence of the "double movement" as argued by Polanyi: on the one hand, it confirms that the socially and environmentally disastrous commodification of land by powerful agribusiness actors was strongest in times of weak state regulation under neoliberal governments. On the other hand, hopes that the "post-neoliberal" state in Brazil and other countries would take the lead of the countermovement were disappointed: left-wing governments, depending on the financial revenues and parliamentary power of export-oriented agribusiness groups, only half-heartedly promoted the re-embedding of land into society and the environment (Vergara-Camus and Kay 2017). Resistance to the commodification of land rather emerged from civil society movements and environmental obstacles on both sides of the Atlantic. All in all, instead of one "great transformation" in the Polanyian sense, we see multiple small (counter-)movements—-some progressive, some reactionary-around the "land question" (Burawoy 2010, p. 311): while some focus on decommodification (e.g. MST), others stick to 
(re-)commodification, either by containing its most disruptive effects (e.g. RTRS) or by shifting it to less contested frontier zones elsewhere (e.g. "Danube Soya").

\section{Conclusion}

This article aims to revise current debates in the field of commodity studies through a Polanyian lens. Polanyi reminds us of the need to pay attention to the double movements in which fictitious commodities are disembedded from and re-embedded in society. We focus on two fictitious commodities, labour and land, which are conventionally treated as mere inputs for the production of genuine commodities, and shift the perspective towards studying them as fictitious commodities in the context of transnational commodity chains. In sum, the dynamics we observe in both fields imply not just simple double movements, but complex entanglements of state, business and civic actors as well as non-human actors involved in the disembedding and re-embedding of labour and land.

Three aspects of these entanglements shall be highlighted. First, countermovements are not always radically directed against commodification, but may rather have a reformist character. In the garment industry, state, civil society and corporate actors in the West as well as in producing countries largely seek to maintain the current business logic, while averting the most detrimental effects for workers. Furthermore, re-embedding efforts may be accompanied by further commodification, such as when garment buyers seek alternative, less regulated sourcing locations or when collective action provides them with increased leverage over factory managers. In the agro-food sector, agribusiness firms as main drivers of capitalist soy expansion in alliance with governments and civic actors also engage in less devastating forms of the commodification of land in order to maintain their business models in the light of public protests. This insight conforms to Hough and Bair (2012, p. 31), who claim that Polanyi is wrong in ascribing all countermovements to "reflexive efforts to protect society from the devastation wrought by novel forms of commodification". Our cases also demonstrate the non-human drivers of countermovements, such as building structures and environmental catastrophes.

Second, Polanyi mainly focused on the state as the driver of countermovements, and indeed states seem to be important in the transnational realm, despite their allegedly limited influence. Fuelled by the Rana Plaza accident, nation states in the West and the Bangladeshi state are intensely involved in attempts to re-embed global garment production, and in turn their involvement is spurred by civil society action. In the agro-food sector, nation states and supra-national organizations such as the EU play ambivalent roles in the de- and recommodification of land, as the process is highly contested between governmental, corporate and civil-society interests. Thus, whereas Burawoy (2010) stresses that countermovements against global capitalism need to start at the transnational level, our cases demonstrate the importance of locallevel, national and transnational action, as well as the interplay between these levels (see Djelic and Quack 2003), especially since regulatory re-embedding efforts tend to privilege powerful actors and their interests. 
Third, our cases show that fictitious commodities are not separated from each other but closely interlinked. The garment industry, for instance, also contributes to about $20 \%$ of industrial water waste and $10 \%$ of global carbon emissions and counts as the world's second largest polluter after the oil industry. Likewise, the land question is also intertwined with the labour question, i.e. the proletarization and even enslavement of displaced smallholders at the Brazilian soy frontier. We see some evidence that countermovements at one end-such as against labour exploitation in Bangladesh or for the self supply of protein-rich feedstuffs in Central, East and Southeast Europe-can work to the detriment of others-such as environmental standards in garment production or the displacement of worker-peasants by large soy farms. Yet, a "real" countermovement would probably have to look at ways of re-embedding land, labour and money jointly, since all three are interlinked in driving the dynamics of contemporary commodity chains.

Funding Open access funding provided by Johannes Kepler University Linz.

Open Access This article is distributed under the terms of the Creative Commons Attribution 4.0 International License (http://creativecommons.org/licenses/by/4.0/), which permits unrestricted use, distribution, and reproduction in any medium, provided you give appropriate credit to the original author(s) and the source, provide a link to the Creative Commons license, and indicate if changes were made.

\section{References}

Alexander, Rachel, Sarah Ashwin, Nora Lohmeyer, Chikako Oka, and Elke Schüßler. 2017. Analysing the evolving texture of transnational industrial relations: Opening the black box of interfirm and firm-union relationships in the global garment industry. http://www.wiwiss.fu-berlin.de/forschung/ Garments/Medien/Discussion-Paper-Garment-Governance-01-2017_Analysing-the-evolvingtexture-of-transnational-industrial-relations1.pdf. Garment Supply Chain Governance Discussion Paper Series 01.

Anner, Mark. 2018. Binding power: The sourcing squeeze, workers' rights, and building safety in Bangladesh since Rana Plaza. http://www.wiwiss.fu-berlin.de/forschung/Garments/Medien/2018Anner-Research-Report-Binding-Power.pdf. Center for Global Workers' Rights Research Report.

Anner, Mark, Jennifer Bair, and Jeremy Blasi. 2013. Toward joint liability in global supply chains: Addressing the root causes of labor violations in international subcontracting networks. Comparative Labor Law and Policy Journal 35(1):1-44.

Bair, Jennifer. 2005. Global capitalism and commodity chains: looking back, going forward. Competition \& Change 9(2):153-180.

Bair, Jennifer. 2008a. Global commodity chains. Genealogy and review. In Frontiers of commodity chain research, ed. Jennifer Bair, 1-34. Stanford: Stanford University Press.

Bair, Jennifer. 2008b. Analysing global economic organization: Embedded networks and global chains compared. Economy and Society 37(3):339-364.

Baumann-Pauly, Dorothee, Sarah Labowitz, and Nate Stein. 2018. Transforming the garment industry in Bangladesh: Sharing responsibility. In Sustainable fashion. Governance and new management approaches, ed. Sarah Margaretha Jastram, Anna-Maria Schneider, 41-50. Cham: Springer.

Beckert, Jens. 2007. The great transformation of embeddedness: Karl Polanyi and the new economic sociology. MPIfG Discussion Paper, Vol. 07(1). Köln: Max Planck Institute for the Study of Societies.

Block, Fred, and Somers, Margaret R. 2014. The power of market fundamentalism. Cambridge: Harvard University Press.

Burawoy, Michael. 2010. From Polanyi to Pollyanna: The false optimism of global labor studies. Global Labour Journal 1(2):301-313.

Cerny, Philip G. 1997. Paradoxes of the competition state: The dynamics of political globalization. Government and Opposition 32(2):251-274.

Cáceres, Daniel M. 2014. Accumulation by dispossession and socio-environmental conflicts caused by the expansion of agribusiness in Argentina. Journal of Agrarian Change 15(1):116-147.

Dale, Gareth. 2010. Karl Polanyi. The limits of the market. Cambridge: Polity Press. 
Djelic, Marie-Laure, and Sigrid Quack (eds.). 2003. Globalization and institutions. Cheltenham: Edward Elgar.

Djelic, Marie-Laure, and Sigrid Quack. 2018. Globalization and business regulation. Annual Review of Sociology https://doi.org/10.1146/annurev-soc-060116-053532.

Faostat. 2018. http://www.fao.org/faostat/en.

Gereffi, Gary. 1994. The organization of buyer-driven global commodity chains: How U.S. retailers shape overseas production networks. In Commodity chains and global capitalism, ed. Gary Gereffi, Miguel Korzeniewicz, 95-122. Westport: Praeger.

Gereffi, Gary. 1995. Global production systems and Third World development. In Global change, regional response: The new international context of development, ed. Barbara Stallings, 100-142. Cambridge: Cambridge University Press.

Gereffi, Gary, John Humphrey, and Timothy Sturgeon. 2005. The governance of global value chains. $R e-$ view of International Political Economy 12(1):78-104.

Harvey, David. 2004. The 'new' imperialism: Accumulation by dispossession. Socialist Register 40:63-87.

Heinrich Böll Foundation. 2014. Meat atlas. Facts and figures about the animals we eat. Berlin: Heinrich Böll Foundation.

Helfen, Markus, Elke Schüßler, and Jörg Sydow. 2018. How can employment relations in global value networks be managed towards social responsibility? Human Relations 71(12):1640-1665. https:// doi.org/10.1177/0018726718757060.

Hess, Martin, and Neil Coe. 2006. Making connections: Global production networks, standards, and embeddedness in the mobile-telecommunications industry. Environment and Planning A: Economy and Space 38(7):1205-1227. https://doi.org/10.1068/a38168.

Hopkins, Terence, and Immanuel Wallerstein. 1977. Patterns of development of the modern world-system. Review 1:11-145.

Hospes, Otto. 2014. Marking the success or end of global multi-stakeholder governance? The rise of national sustainability standards in Indonesia and Brazil for palm oil and soy. Agriculture and Human Values 31(3):425-437.

Hough, Phillip A., and Jennifer Bair. 2012. Dispossession, class formation, and the political imaginary of Colombia's coffee producers over the longue duree: Beyond the Polanyian analytic. Journal of WorldSystems Research 18(1):30-49.

Humphrey, John, and Schmitz, Hubert. 2000. Governance and upgrading: linking industrial cluster and global value chain research. Vol. 120. Brighton: Institute of Development Studies.

Kabeer, Naila, and Simeen Mahmud. 2004. Globalization, gender and poverty: Bangladeshi women workers in export and local markets. Journal of International Development 16(1):93-109.

Krausmann, Fridolin and Ernst Langthaler. 2019. Food regimes and their trade links: A socio-ecological perspective. Ecological Economics 160:87-95. https://doi.org/10.1016/j.ecolecon.2019.02.011.

Krön, Matthias, and Ursula Bittner. 2015. Danube soya-improving European GM-free soya supply for food and feed. Oilseeds and Fats, Crops and Lipids 22(5):1-10. https://doi.org/10.1051/oc1/2015050.

Langthaler, Ernst. 2015. Gemüse oder Ölfrucht? Die Weltkarriere der Sojabohne im 20. Jahrhundert. In Umkämpftes Essen. Produktion, Handel und Konsum von Lebensmitteln in globalen Kontexten, ed. Cornelia Reiher, Sarah Ruth Sippel, 41-66. Göttingen: Vandenhoeck \& Ruprecht.

Langthaler, Ernst. 2018. The soy paradox. The Western nutrition transition revisited, 1950-2010. Global Environment 11(1):79-104. https://doi.org/10.3197/ge.2018.110105.

Lapegna, Pablo. 2016. Soybeans and power: Genetically modified crops, environmental politics, and social movements in Argentina. Oxford: Oxford University Press.

Lohmeyer, Nora, and Elke Schüßler. 2018. Rana Plaza as a threat to the fast fashion model? An analysis of institutional responses to the disaster in Germany. In Eco-friendly and fair: Fast fashion and consumer behaviour, ed. Carolin Becker-Leifhold, Mark Heuer, 3-14. London, New York: Routledge.

Lohmeyer, Nora, Elke Schüßler, and Markus Helfen. 2018. Can solidarity be organized "from below" in global supply chains? The case of ExChains. Industrielle Beziehungen 25(4):400-424.

Mazzucato, Mariana. 2011. The entrepreneurial state. London: Demos.

McMichael, Philip. 2013. Food regimes and agrarian questions. Halifax, Winnipeg: Fernwood Publishing.

Osterhammel, Jürgen, and Niels P. Petersson. 2003. Geschichte der Globalisierung: Dimensionen, Prozesse, Epochen. Munich: Beck.

Polanyi, Karl. 2001. The great transformation. The political and economic origins of our time. Boston: Beacon Press.

Robles, Wilder, and Henry Veltmeyer. 2015. The politics of agrarian reform in Brazil. The landless rural workers movement. New York: Palgrave Macmillan. 
Sammond, Nicholas. 2007. Commodities, commodity fetishism, and commodification. In The Blackwell encyclopedia of sociology, ed. George Ritzer, 607-612. Malden: Blackwell Publishing.

Schuessler, Elke, Stephen Jerome Frenkel, and Chris F. Wright. 2018. Governance of labor standards in Australian and German garment supply chains: The Impact of Rana Plaza. ILR Review https://doi. org/10.1177/0019793918771360.

Schüßler, Elke. 2009. Strategische Prozesse und Persistenzen: Pfadabhängige Organisation der Wertschöpfung in der Bekleidungsindustrie. Stuttgart: Kohlhammer.

Schüßler, Elke, Stephen Jerome Frenkel, Sarah Ashwin, Naila Kabeer, Niklas Egels-Zandén, Lopita Huq, Rachel Alexander, Chika Oka, Nora Lohmeyer, Shahidur Rahman, and Kazi Mahmudur Rahman. 2019. Changes in the governance of garment global production networks: Lead firm, supplier and institutional responses to the Rana Plaza disaster (version 1.1). http://www.wiwiss.fu-berlin. de/forschung/Garments/Medien/GarmentGov_Interim-Report_January2019FINAL_2.pdf. Garment Supply Chain Governance Interim Report January 2019.

Steger, Manfred. 2009. Globalization. A very short introduction. Oxford: Oxford University Press.

Tooze, Adam. 2014. The deluge: The Great War and the remaking of global order, 1916-1931. London: Allen Lane.

Tooze, Adam. 2018. Crashed: How a decade of financial crises changed the world. London: Allen Lane.

Turzi, Mariano. 2017. The political economy of agricultural booms: Managing soybean production in Argentina, Brazil, and Paraguay. Cham: Palgrave Macmillan.

United Nations Conference on Trade and Development (unctad). 2013. World investment report 2013: Global value chains: Investment and trade for development. https://unctad.org/en/PublicationsLibrary/ wir2013_en.pdf.

Vergara-Camus, Leandro, and Cristóbal Kay. 2017. The agrarian political economy of left-wing governments in Latin America: Agribusiness, peasants, and the limits of neo-developmentalism. Journal of Agrarian Change 17(2):415-437.

Vorley, Bill. 2003. Food, Inc.: Corporate concentration from farm to consumer. London: Food Group.

Wallerstein, Immanuel. 1974. The modern world-system I: Capitalist agriculture and the origins of the European world-economy in the sixteenth century. New York: Academic Press.

Wallerstein, Immanuel. 1983. Historical capitalism. New York: Verso.

Weis, Tony. 2013. The ecological hoofprint: The global burden of industrial livestock. London: Zed Books.

Ernst Langthaler is Professor of Social and Economic History at Johannes Kepler University Linz. His research interests include agricultural, food and environmental history, 19th to 21st centuries, with a focus on commodity chains. Latest monograph: Agro-Food Studies (with Ulrich Ermann, Marianne Penker and Markus Schermer).

Elke Schüßler is Professor of Business Administration and Head of the Institute of Organization Science at Johannes Kepler University Linz. Her research encompasses labour and environmental standards, global supply chains, institutional theory, and organizational change and innovation. 